\title{
Work factors and behavioural coping in relation to withdrawal from the labour force in patients with rheumatoid arthritis
}

\author{
A M J Chorus, H S Miedema, C W J Wevers, $S$ van der Linden
}

\begin{abstract}
Objective-To assess separate and combined effects of work factors and behavioural coping in relation to withdrawal from the labour force among patients with rheumatoid arthritis (RA).

Methods-A cross sectional study was conducted in a Dutch nationwide random sample of 720 patients with RA. Information about work factors and behavioural coping was collected by a self-administered postal questionnaire. A broad variety of work factors and coping styles were evaluated separately and in combination using multivariate logistic regression analyses, controlling for sociodemographic and disease related variables. Attributable and preventable fractions were calculated from the combined analyses to assess the relative importance of the contributing factors.

Results-Additional job training, equal career opportunities, letting the disease influence the choice of the current job position, and informing colleagues about having the disease were negatively associated with withdrawal from the labour force. The most relevant factor in terms of decreasing the risk was adjusting job demands which accounted for $63 \%$ of the patients still in the labour force. Decreasing activities and diverting attention in order to cope with pain, and pacing in order to cope with limitations were the coping styles which were positively associated with withdrawal from the labour force. The most relevant factor in terms of increasing the risk of withdrawal was pacing which accounted for $67 \%$ of the withdrawals.

Conclusion-Work factors are potentially important modifiable risk factors for withdrawal from the labour force in patients with RA. Behavioural coping is also relevant.

(Ann Rheum Dis 2001;60:1025-1032)
\end{abstract}

Rheumatoid arthritis (RA) is a disease with spontaneous exacerbations and remissions, and its course is largely unpredictable. It may Internal

Medicine/Rheumatology, University Hospital

Maastricht, The

Netherlands

$\mathrm{S}$ van der Linden

Correspondence to:

Ms A M J Chorus

AMJ.Chorus@pg.tno.nl

Accepted 12 April 2001 disease reaches a peak between the ages of 40 and 50. Over the past two decades various studies have addressed early withdrawal of patients with RA from the labour force..$^{2-6}$ We have previously reported that participation in the labour force by patients with RA is only slightly lower than for the general working population after controlling for age, sex, and educational level. ${ }^{7}$ This implies that, despite active disease, many patients with RA are managing to continue to work.

It has been shown that sociodemographic variables, disease related factors, and work characteristics are related to participation in the labour force by patients with RA. Higher age and lower educational level are important sociodemographic risk factors of withdrawal from the labour force by these patients. ${ }^{7}$ Pain, deformities, extra-articular disease, and other manifestations of the disease process are important disease related risk factors of withdrawal from the labour force. However, it is also well known that patients with RA with comparable levels of disease activity and impairment may differ greatly in work disability. ${ }^{8}$ A recent study has shown that early and aggressive antirheumatic treatment does not seem to reduce early withdrawal from the labour force. ${ }^{5}$ Increasingly, various work factors have been identified as risk factors. A physically demanding job, lack of control over the pace and activities of work, no selfemployment status, lack of support by employers and colleagues, and also difficulties in commuting are important factors for leaving the labour force. ${ }^{2-12}$ Despite this valuable knowledge, it is still not clear which factors are most important. Some studies point out that disease related factors are most important, ${ }^{912}$ whereas others conclude that work factors are the most important predictors of withdrawal from the labour force. ${ }^{11}$

Another explanation for differences in work disability in RA among otherwise comparable patients might be the way in which patients deal with the biological consequences of their disease - that is, behavioural coping. Coping in RA has been extensively investigated and it is generally found that what individuals do in relation to the stresses of the disease has potentially important implications for their levels of disability and psychological well being. ${ }^{13}$ Some patients may function to the limit of their capacities while others refrain from activities of which they are still capable. Pain, limitations, and dependency are identified as the most important chronic stressors of RA. ${ }^{14}$ Limiting the level of activity when faced with the 
Table 1 Characteristics of patients withdrawn from labour force after diagnosis and patients still in paid employment

\begin{tabular}{|c|c|c|c|}
\hline Variable & Category & $\begin{array}{l}\% R A \text { patients } \\
\text { withdrawn from } \\
\text { labour force after } \\
\text { diagnosis }(n=343)\end{array}$ & $\begin{array}{l}\% R A \text { patients in } \\
\text { paid employment at } \\
\text { time of study } \\
(n=377)\end{array}$ \\
\hline $\operatorname{Sex}(\%)^{\star}$ & Male & 29.9 & 43.9 \\
\hline Age at time of study (years) ${ }^{\star}$ & $\begin{array}{l}20-29 \\
30-39 \\
40-49 \\
50-59\end{array}$ & $\begin{array}{l}1.8 \\
10.2 \\
27.5 \\
60.2\end{array}$ & $\begin{array}{l}6.2 \\
14.9 \\
42.7 \\
36.2\end{array}$ \\
\hline Educational level $^{\star}$ & $\begin{array}{l}\text { Primary } \\
\text { Secondary } \\
\text { Higher vocational education/university }\end{array}$ & $\begin{array}{l}52.0 \\
39.9 \\
8.1\end{array}$ & $\begin{array}{l}32.5 \\
47.3 \\
20.2\end{array}$ \\
\hline Age at diagnosis of RA (years) & $\begin{array}{l}<20 \\
20-29 \\
30-39 \\
40-49 \\
50-59\end{array}$ & $\begin{array}{l}8.2 \\
21.9 \\
28.5 \\
30.2 \\
11.2\end{array}$ & $\begin{array}{l}9.6 \\
19.5 \\
32.3 \\
30.9 \\
7.6\end{array}$ \\
\hline Disease duration at time of study (years) ${ }^{\star}$ & $\begin{array}{l}2-5 \\
6-10 \\
11-15 \\
16-20 \\
>20\end{array}$ & $\begin{array}{l}19.3 \\
23.9 \\
17.8 \\
17.0 \\
22.0\end{array}$ & $\begin{array}{l}32.1 \\
32.8 \\
17.3 \\
9.5 \\
8.4\end{array}$ \\
\hline Disease activity ${ }^{\star}$ & RADAI (mean 0-10) & 4.9 & 3.5 \\
\hline Functional ability* & HAQ (mean 0-3) & 1.3 & 0.7 \\
\hline $\begin{array}{l}\text { Duration of labour force participation } \\
\text { after diagnosis with RA (years) }{ }^{\star}\end{array}$ & $\begin{array}{l}0-1 \\
2-4 \\
5-7 \\
8-12 \\
>12\end{array}$ & $\begin{array}{l}45.4 \\
18.5 \\
13.3 \\
11.3 \\
11.5\end{array}$ & $\begin{array}{l}1.7 \\
23.0 \\
26.0 \\
25.0 \\
24.3\end{array}$ \\
\hline Work disability pension & $\begin{array}{l}\geqslant 80 \% \text { disabled } \\
<80 \% \text { disabled }^{\star}\end{array}$ & $\begin{array}{l}68.9 \\
25.5\end{array}$ & $\begin{array}{l}\text { NA } \\
14.4\end{array}$ \\
\hline
\end{tabular}

$\star$ Differences between group means and distributions are statistically significant $(\mathrm{p}<0.05)$.

$\mathrm{NA}=$ not applicable.

stressors of the disease may have negative effects on future physical functioning. ${ }^{1516} \mathrm{At}$ work a patient's behavioural reaction to these stressors may also be an important factor in determining the patient's work capacity. Nevertheless, the relation between coping and participation in the labour force in RA has, as yet, not been explored.

Both work factors and coping skills are potentially modifiable and could be used to construct vocational interventions to prevent early withdrawal from the labour force. ${ }^{817}$ The purpose of this study is to explore modifiable factors other than disease modifying factors which could prevent or postpone early withdrawal from the labour force. We therefore examined a variety of work factors and behavioural coping styles in a representative Dutch sample of patients with RA who had held a paid job any time after being diagnosed with RA. The study aimed to assess the effects of work factors and behavioural coping on withdrawal from the labour force by patients with RA, controlling for confounding effects of sociodemographic and disease related factors.

\section{Methods}

PATIENTS AND MATERIALS

The study was conducted in a nationwide group of 1056 Dutch patients with RA aged 20-59 years diagnosed by a rheumatologist. Eligible patients were identified using the national Standardised Diagnosis Register of Rheumatic Diseases (SDR), a representative database with information about diagnoses of the patient population from $80 \%$ of all rheumatologists in the Netherlands. ${ }^{18}$ From this database a random sample of patients with RA aged 16-59 years was selected from a geographically representative sample of 35 rheumatologists (37\% of all SDR rheumatologists) in 17 practices $(52 \%$ of all SDR practices) throughout the Netherlands. All patients were contacted by mail by their own rheumatologist and $1056(62 \%)$ agreed to participate in the study. At the time of the study three quarters of the patients fulfilled four or more of the 1987 ACR criteria and more than $80 \%$ were receiving DMARD therapy. All patients filled out a self-administered questionnaire containing several standardised instruments. Data were obtained on sociodemographic factors, disease characteristics, functional abilities, health related quality of life, present and past working conditions, and coping with the disease. The design of the study has also been described in detail elsewhere.

For the present analysis, the study group was limited further to include only those patients with paid employment at the time of diagnosis or at any time after being diagnosed with RA $(n=720,68.2 \%)$. The other 336 patients had either stopped working before diagnosis $(n=235,22.2 \%)$ or had no work history $(n=101,9.6 \%)$ and were therefore not included in the analysis.

SOCIODEMOGRAPHIC VARIABLES AND DISEASE CHARACTERISTICS

Age, sex, educational level, disease duration, and disease activity are important risk factors for leaving the labour force. Since the 
present study focused on work factors and coping styles, sociodemographic variables and disease characteristics were considered to be confounding factors in the relation between work factors or coping styles and withdrawal from the labour force. Educational level was separated into three categories based on the Dutch school system (primary education (0-8 years), secondary education (9-16 years), and higher vocational education/university (17+ years). An index for disease activity was constructed from five questions of the Rapid Assessment of Disease Activity in Rheumatology (RADAR) instrument ${ }^{19}$ using the method described by Stucki et al. ${ }^{20}$ This index, the Rheumatoid Arthritis Disease Activity Index
(RADAI), may vary from 0 to 10 and higher scores indicate higher disease activity.

Functional abilities in daily life were assessed using the Dutch validated version of the Health Assessment Questionnaire containing 20 items addressing eight dimensions of activities of daily life. An overall score was calculated as the mean score of the individual mean scores for the items in the eight dimensions. ${ }^{21}$

WORK FACTORS

All patients reported on their work history using a Dutch generic structured instrument, the Vocational Handicap Questionnaire (VHQ), which had been validated in previous studies in chronically ill Dutch people. ${ }^{22-24}$ This

Table 2 Distribution and odds ratios of withdrawal from the labour force by patients with rheumatoid arthritis for various work factors

\begin{tabular}{|c|c|c|c|c|}
\hline Work factors & Categories & $\begin{array}{l}\% \text { of } R A \text { patients } \\
\text { withdrawn from the } \\
\text { labour force after } \\
\text { diagnosis ( } n=343 \text { ) }\end{array}$ & $\begin{array}{l}\% \text { of } R A \text { patients in } \\
\text { paid employment at } \\
\text { time of study } \\
\text { ( } n=377)\end{array}$ & $O R^{*}(95 \% C I)$ \\
\hline Field of work & $\begin{array}{l}\text { Administrative } \\
\text { Agricultural } \\
\text { Manual/industrial } \\
\text { Transport } \\
\text { Commercial } \\
\text { Service/sales } \\
\text { Professional }\end{array}$ & $\begin{array}{r}16.9 \\
1.9 \\
22.1 \\
3.8 \\
13.4 \\
24.8 \\
17.1\end{array}$ & $\begin{array}{r}23.3 \\
3.3 \\
14.1 \\
3.6 \\
11.8 \\
16.5 \\
27.5\end{array}$ & $\begin{array}{l}1.0 \\
0.9(0.3 \text { to } 3.0) \\
3.2(1.6 \text { to } 6.4) \\
2.1(0.7 \text { to } 6.2) \\
1.6(0.8 \text { to } 3.0) \\
1.8(1.0 \text { to } 3.2) \\
1.2(0.6 \text { to } 2.4)\end{array}$ \\
\hline Size of company (no. of employees) & $\begin{array}{l}<100 \\
\geqslant 100\end{array}$ & $\begin{array}{l}69.1 \\
30.9\end{array}$ & $\begin{array}{l}59.3 \\
40.7\end{array}$ & $\begin{array}{l}1.3(0.9 \text { to } 2.0) \\
1.0\end{array}$ \\
\hline Temporary job position & $\begin{array}{l}\text { No } \\
\text { Yes }\end{array}$ & $\begin{array}{r}93.3 \\
6.7\end{array}$ & $\begin{array}{r}92.2 \\
7.8\end{array}$ & $\begin{array}{l}1.0 \\
1.5(0.8 \text { to } 3.0)\end{array}$ \\
\hline Executive position & $\begin{array}{l}\text { No } \\
\text { Yes }\end{array}$ & $\begin{array}{l}74.6 \\
25.4\end{array}$ & $\begin{array}{l}68.3 \\
31.7\end{array}$ & $\begin{array}{l}1.0 \\
1.0(0.6 \text { to } 1.5)\end{array}$ \\
\hline Number of working hours & $\begin{array}{l}<32.0 / \text { week } \\
\geqslant 32.0 / \text { week }\end{array}$ & $\begin{array}{l}38.8 \\
61.2\end{array}$ & $\begin{array}{l}47.3 \\
52.7\end{array}$ & $\begin{array}{l}0.3(0.2 \text { to } 0.5) \\
1.0\end{array}$ \\
\hline Additional job training after diagnosis & $\begin{array}{l}\text { No } \\
\text { Yes }\end{array}$ & $\begin{array}{l}54.9 \\
45.1\end{array}$ & $\begin{array}{l}32.3 \\
67.7\end{array}$ & $\begin{array}{l}1.0 \\
0.5(0.4 \text { to } 0.8)\end{array}$ \\
\hline Changed field of activity after diagnosis & $\begin{array}{l}\text { No } \\
\text { Yes }\end{array}$ & $\begin{array}{l}80.2 \\
19.8\end{array}$ & $\begin{array}{l}73.7 \\
26.3\end{array}$ & $\begin{array}{l}1.0 \\
0.7(0.5 \text { to } 1.1)\end{array}$ \\
\hline $\begin{array}{l}\text { RA influenced choice on last/present job } \\
\text { position }\end{array}$ & $\begin{array}{l}\text { No } \\
\text { Yes }\end{array}$ & $\begin{array}{l}79.3 \\
20.7\end{array}$ & $\begin{array}{l}68.7 \\
31.3\end{array}$ & $\begin{array}{l}1.0 \\
0.5(0.4 \text { to } 0.8)\end{array}$ \\
\hline Accessibility of work place & $\begin{array}{l}\text { Good } \\
\text { Bad }\end{array}$ & $\begin{array}{l}76.5 \\
23.5\end{array}$ & $\begin{array}{r}93.4 \\
6.6\end{array}$ & $\begin{array}{l}1.0 \\
4.8(2.6 \text { to } 9.1)\end{array}$ \\
\hline Transportation mobility & $\begin{array}{l}\text { Not reduced } \\
\text { Reduced }\end{array}$ & $\begin{array}{l}83.5 \\
16.5\end{array}$ & $\begin{array}{r}95.7 \\
4.3\end{array}$ & $\begin{array}{l}1.0 \\
5.0(2.5 \text { to } 10.0)\end{array}$ \\
\hline Adjusted working hours & $\begin{array}{l}\text { No } \\
\text { Yes }\end{array}$ & $\begin{array}{l}86.2 \\
13.8\end{array}$ & $\begin{array}{l}72.5 \\
27.5\end{array}$ & $\begin{array}{l}1.0 \\
0.3(0.2 \text { to } 0.5)\end{array}$ \\
\hline Adjusted job demands & $\begin{array}{l}\text { No } \\
\text { Yes }\end{array}$ & $\begin{array}{l}84.9 \\
15.1\end{array}$ & $\begin{array}{l}69.6 \\
17.2\end{array}$ & $\begin{array}{l}1.0 \\
0.3(0.2 \text { to } 0.5)\end{array}$ \\
\hline Technical adjustments & $\begin{array}{l}\text { No } \\
\text { Yes }\end{array}$ & $\begin{array}{r}93.6 \\
6.4\end{array}$ & $\begin{array}{l}82.8 \\
17.2\end{array}$ & $\begin{array}{l}1.0 \\
0.3(0.2 \text { to } 0.6)\end{array}$ \\
\hline Dependent on colleagues & $\begin{array}{l}\text { No } \\
\text { Yes }\end{array}$ & $\begin{array}{l}53.5 \\
46.5\end{array}$ & $\begin{array}{l}62.3 \\
37.7\end{array}$ & $\begin{array}{l}1.0 \\
1.1(0.8 \text { to } 1.6)\end{array}$ \\
\hline Attitude of colleagues towards patient & $\begin{array}{l}\text { Normal/positive } \\
\text { Negative }\end{array}$ & $\begin{array}{l}89.7 \\
10.3\end{array}$ & $\begin{array}{r}94.8 \\
5.2\end{array}$ & $\begin{array}{l}1.0 \\
1.8 \text { (1.0 to } 3.6)\end{array}$ \\
\hline Support of colleagues & $\begin{array}{l}\text { Sufficient } \\
\text { Insufficient }\end{array}$ & $\begin{array}{l}73.7 \\
26.3\end{array}$ & $\begin{array}{r}94.8 \\
5.2\end{array}$ & $\begin{array}{l}1.0 \\
4.9(2.7 \text { to } 8.9)\end{array}$ \\
\hline Colleagues well informed about RA & $\begin{array}{l}\text { No } \\
\text { Yes }\end{array}$ & $\begin{array}{l}22.2 \\
77.8\end{array}$ & $\begin{array}{r}9.7 \\
90.3\end{array}$ & $\begin{array}{l}1.0 \\
0.3(0.2 \text { to } 0.5)\end{array}$ \\
\hline Coaching of management & $\begin{array}{l}\text { Sufficient } \\
\text { Insufficient }\end{array}$ & $\begin{array}{l}64.4 \\
35.6\end{array}$ & $\begin{array}{r}91.8 \\
8.2\end{array}$ & $\begin{array}{l}1.0 \\
5.8(3.3 \text { to } 9.9)\end{array}$ \\
\hline Career opportunities within companyE & $\begin{array}{l}\text { Equal to colleagues } \\
\text { Less than colleagues }\end{array}$ & $\begin{array}{l}60.5 \\
39.5\end{array}$ & $\begin{array}{l}70.3 \\
29.7\end{array}$ & $\begin{array}{l}1.0 \\
1.6(1.1 \text { to } 2.4)\end{array}$ \\
\hline
\end{tabular}

*All odds ratios (ORs) and their 95\% confidence intervals (CI) were adjusted for age, sex, educational level, disease activity, and disease duration. Bold type indicates statistically significant differences between the groups. 
Table 3 Distribution and odds ratios of withdrawal from the labour force by rheumatoid arthritis patients for various coping styles

\begin{tabular}{|c|c|c|c|c|}
\hline Coping styles & Categories & $\begin{array}{l}\% \text { of } R A \text { patients } \\
\text { withdrawn from the } \\
\text { labour force after } \\
\text { diagnosis }(n=343)\end{array}$ & $\begin{array}{l}\% \text { of } R A \text { patients in paid } \\
\text { employment at time of } \\
\text { study }(n=377)\end{array}$ & $O R^{\star}(95 \% C I)$ \\
\hline \multicolumn{5}{|l|}{ Pain } \\
\hline Comforting cognition & $\begin{array}{l}\text { Never/sometimes } \\
\text { (very) often }\end{array}$ & $\begin{array}{l}12.6 \\
87.4\end{array}$ & $\begin{array}{l}13.3 \\
86.7\end{array}$ & $\begin{array}{l}1.0 \\
0.8(0.5 \text { to } 1.4)\end{array}$ \\
\hline Decreasing activity & $\begin{array}{l}\text { Never/sometimes } \\
\text { (very) often }\end{array}$ & $\begin{array}{l}32.9 \\
67.1\end{array}$ & $\begin{array}{l}69.1 \\
30.9\end{array}$ & $\begin{array}{l}1.0 \\
3.6(2.5 \text { to } 5.3)\end{array}$ \\
\hline Diverting attention & $\begin{array}{l}\text { Never/sometimes } \\
\text { (very) often }\end{array}$ & $\begin{array}{l}56.0 \\
44.0\end{array}$ & $\begin{array}{l}66.0 \\
34.0\end{array}$ & $\begin{array}{l}1.0 \\
1.6(1.1 \text { to } 2.3)\end{array}$ \\
\hline $\begin{array}{l}\text { Limitations } \\
\text { Optimism }\end{array}$ & $\begin{array}{l}\text { Never/sometimes } \\
\text { (very) often }\end{array}$ & $\begin{array}{l}15.3 \\
84.7\end{array}$ & $\begin{array}{l}14.1 \\
85.9\end{array}$ & $\begin{array}{l}1.0 \\
0.6(0.4 \text { to } 1.0)\end{array}$ \\
\hline Pacing & $\begin{array}{l}\text { Never/sometimes } \\
\text { (very) often }\end{array}$ & $\begin{array}{l}14.9 \\
85.1\end{array}$ & $\begin{array}{l}46.2 \\
53.8\end{array}$ & $\begin{array}{l}1.0 \\
3.8(2.5 \text { to } 5.7)\end{array}$ \\
\hline Creative solutions & $\begin{array}{l}\text { Never/sometimes } \\
\text { (very) often }\end{array}$ & $\begin{array}{l}34.9 \\
65.1\end{array}$ & $\begin{array}{l}44.9 \\
55.1\end{array}$ & $\begin{array}{l}1.0 \\
1.3(0.9 \text { to } 1.8)\end{array}$ \\
\hline $\begin{array}{r}\text { Dependence } \\
\text { Accepting }\end{array}$ & $\begin{array}{l}\text { Never/sometimes } \\
\text { (very) often }\end{array}$ & $\begin{array}{l}53.9 \\
46.1\end{array}$ & $\begin{array}{l}62.1 \\
37.9\end{array}$ & $\begin{array}{l}1.0 \\
1.2(0.9 \text { to } 1.8)\end{array}$ \\
\hline Consideration & $\begin{array}{l}\text { Never/sometimes } \\
\text { (very) often }\end{array}$ & $\begin{array}{l}27.2 \\
72.8\end{array}$ & $\begin{array}{l}32.7 \\
67.3\end{array}$ & $\begin{array}{l}1.0 \\
0.8(0.5 \text { to } 1.1)\end{array}$ \\
\hline
\end{tabular}

*All odds ratios (ORs) and their $95 \%$ confidence intervals (CI) were adjusted for age, sex, educational level, disease activity and disease duration. Bold printed ORs and $95 \% \mathrm{CI}$ indicate statistically significant differences between groups.

questionnaire assesses present occupational situation, vocational handicaps, and past working career. Data were therefore collected for the year of first real paid job, size of company, job demands, accessibility of the work place and transportation mobility, job adjustments, relationship with people in the work place, and career opportunities. Patients who had withdrawn from the labour force were asked to indicate whether they had left the labour force for work related reasons, disease related reasons, or other personal reasons.

BEHAVIOURAL COPING

Behavioural coping styles were assessed by the validated Coping with Rheumatic Stressors (CORS) instrument which was originally drafted in Dutch. ${ }^{1425}$ The CORS measures eight coping styles for the most important chronic stressors of RA-that is, pain, limitations, and dependence. Three coping scales refer to pain: comforting cognitions ( 9 items), decreasing activities ( 8 items), and diverting attention (8 items). Three scales measure styles of coping with limitations: optimism ( 5 items), pacing - for example, adapting one's level of activity (10 items), and creative solution seeking ( 8 items). Two scales refer to dependence: making an effort to accept one's dependence ( 6 items) and showing consideration (7 items). For every item, patients report how often they made use of that particular coping tactic (seldom or never, sometimes, often, very often).

DATA ANALYSIS

Sociodemographic and disease characteristics were analysed by $\chi^{2}$ tests to determine proportional variance between the groups and $t$ tests were conducted to analyse differences between group means for patients who had withdrawn from the labour force and patients who still had paid employment at the time of the study.
The relative risk of withdrawal from the labour force associated with specific work related factors and coping strategies was estimated by comparing variables of the patients who had withdrawn from the labour force with those who had not, adjusted for confounding effects of sociodemographic and disease characteristics. We therefore performed unconditional logistic regression analysis to calculate odds ratios (ORs) and their 95\% confidence intervals (CI) for each work related factor and coping strategy separately. An OR of 1.0 indicates that the exposure to a certain factor by patients with RA who have withdrawn from the labour force is similar to that of patients who still have paid employment; an OR of $<1.0$ indicates that patients with $R A$ who have withdrawn from the labour force are less exposed to a certain factor than those who still have paid employment; and an OR of $>1.0$ indicates that patients with RA who have withdrawn from the labour force are more often exposed to a certain factor than patients who still have paid employment. The 95\% confidence interval indicates whether the differences between the two groups are statistically significant for a certain factor. If an OR of 1.0 is included in the interval, this implies that the estimate is not statistically significant at the $\alpha=0.05$ level. ${ }^{26} 27$ In evaluating the association between withdrawal from the labour force and several work factors, we compared the characteristics of the present jobs of patients with the characteristics of the last job of patients who had withdrawn from the labour force. For each work factor we calculated odds ratios in separate logistic regression models, together with their 95\% confidence intervals, adjusted for age, sex, educational level, disease activity, and disease duration. The same was done to evaluate the relation between withdrawal from the labour force and several coping strategies. For clinical interpretation, we treated variables 
of different coping strategies as dummy variables. The total score for each coping scale was therefore divided by the total number of items it included and the scores were then divided into two categories (scores 1.0-2.5 = never and sometimes; $2.5-4.0=$ often and very often).

In addition, we performed a logistic regression analysis to assess the importance of work factors and coping styles in the relationship with withdrawal from the labour force in a multivariate context. With a forward stepwise procedure, all work related variables and variables for coping styles were admitted to the regression model after variables for age (as a continuous variable), sex (male versus female), educational level (high versus primary/ secondary versus primary), disease duration (as a continuous variable), and disease activity (as a continuous variable) had been entered in the first regression model without selection using statistical thresholds. A variable for work or coping was entered into the equation when the alpha level of rejecting the null hypothesis was 0.2. This level was chosen to ensure adequate power. Based on the final logistic regression model of the stepwise procedure, attributable fractions and preventable fractions were subsequently calculated to estimate the overall proportion of withdrawals from the labour force that could be either attributed to, or prevented by, work factors and coping styles. The adjusted attributable fraction is the proportion of withdrawals from the labour force which is attributed to exposure by that factor. It is calculated as the exposed proportion of patients withdrawn from the labour force multiplied by $(\mathrm{aOR}-1) / \mathrm{aOR}$ where $\mathrm{aOR}$ is the odds ratio for that risk factor adjusted for all other factors in the final model. The adjusted preventable fraction is the proportion of withdrawals in a situation of non-exposure that could be prevented by exposure to that factor and is calculated as the unexposed proportion of patients withdrawn multiplied by $(1-\mathrm{aOR}) .^{27}$
To examine possible recall bias we performed the same stepwise forward multivariate regression analysis with a subsample of patients who had withdrawn from the labour force during the 6 years before the study. The cut off point of 6 years was chosen to ensure adequate power. ${ }^{27}$

All statistical analyses were performed with SPSS for Windows, version 10.0.7.

\section{Results}

Of the 720 patients, 343 (47.6\%) had withdrawn from the labour force after a mean disease duration of 4.8 years; $69.8 \%$ of these patients indicated that they had stopped working as a consequence of RA. Table 1 lists the sociodemographic characteristics and disease specific variables of the study group. At the time of the study patients who had left the labour force had a mean age of 50.1 years whereas patients with a paid job had a mean age of 45.8 years $(p<0.05)$. A significantly higher proportion of patients who had left the labour force were women and they were less highly educated than patients who still had paid employment. Furthermore, patients who had withdrawn from the labour force experienced significantly higher disease activity, longer disease duration, and more disabilities than patients still working. These variables are considered as important confounders in evaluating the relation between work factors and withdrawal from the labour force and evaluating coping and withdrawal from the labour force in patients with RA.

The mean age at diagnosis of RA was 36.4 years for patients who had withdrawn from the labour force and 36.0 years for patients who still had paid employment. More than $40 \%$ of the patients who had withdrawn from the labour force did so within the first year after diagnosis, and $74.6 \%$ of them indicated that RA was the reason for leaving. Most of the patients $(94.4 \%)$ who had withdrawn from the labour force were officially recognised as being

Table 4 Importance of work factors and coping variables for withdrawal from the labour force, taking into account age, sex, educational level, disease activity, and disease duration; attributable and preventable fractions *

\begin{tabular}{|c|c|c|c|c|c|}
\hline Factor (exposed/non-exposed) $\dagger$ & $a O R \neq$ & $\begin{array}{l}\text { Proportion of } R A \\
\text { patients withdrawn } \\
\text { from the labour force } \\
\text { exposed to the factor }\end{array}$ & Attributable fraction & $\begin{array}{l}\text { Proportion of } R A \\
\text { patients withdrawn } \\
\text { from the labour force } \\
\text { not exposed to the factor }\end{array}$ & Preventable fraction \\
\hline $\begin{array}{l}\text { Pain coping style: decreasing activities ((very) often } v \\
\text { sometimes/never) }\end{array}$ & 3.2 & 0.67 & $46 \%$ & & \\
\hline Adjusted job demands (yes $v$ no) & 0.26 & & & 0.85 & $63 \%$ \\
\hline Coaching of management (insufficient $v$ sufficient) & 4.1 & 0.64 & $48 \%$ & & \\
\hline Colleagues well informed about RA (yes $v$ no) & 0.24 & & & 0.22 & $18 \%$ \\
\hline $\begin{array}{l}\text { Limitations coping style: pacing (very often/often } v \\
\text { sometimes/never) }\end{array}$ & 4.6 & 0.85 & $67 \%$ & & \\
\hline Number of working hours $(<32 \mathrm{~h} / \mathrm{w} v \geqslant 32 \mathrm{~h} / \mathrm{w})$ & 0.31 & & & 0.61 & $42 \%$ \\
\hline Mobility in transportation (reduced $v$ not reduced) & 3.6 & 0.17 & $12 \%$ & & \\
\hline Accessibility of workplace (bad $v$ good) & 3.5 & 0.24 & $17 \%$ & & \\
\hline Additional job training after diagnosis (yes $v$ no) & 0.46 & & & 0.55 & $29 \%$ \\
\hline $\begin{array}{l}\text { RA influenced choice of last/present job position (yes } v \\
\text { no) }\end{array}$ & 0.39 & & & 0.79 & $48 \%$ \\
\hline $\begin{array}{l}\text { Career opportunities within company (less equal to } \\
\text { colleagues } v \text { equal) }\end{array}$ & 1.6 & 0.40 & $15 \%$ & & \\
\hline $\begin{array}{l}\text { Limitations coping style: optimism (very often/often } v \\
\text { sometimes/never) }\end{array}$ & 0.56 & & & 0.15 & $6 \%$ \\
\hline Temporary job position (yes $v$ no) & 2.1 & 0.07 & $4 \%$ & & \\
\hline
\end{tabular}

*If a factor is positively associated with withdrawal from the labour force the proportion of patients with RA withdrawn exposed to that factor and the attributable fraction is presented; if a factor is negatively associated then the proportion of patients with RA withdrawn from the labour force not exposed to that factor and the preventable fraction is presented.

tVariables are listed in order of their entry into the regression.

$\ddagger \mathrm{aOR}=$ adjusted odds ratio (controlled for all variables presented in the table including age, sex, educational level, disease activity, and disease duration). 
fully or partially disabled for work purposes since they received a government work disability pension. Partial work disability was recognised in $14 \%$ of the patients who still had paid employment. The social security system of the Netherlands entitles employees who are on full or partial sick leave for more than 1 year to a work disability pension after work disability is officially recognised on the basis of a medical and ergonomic examination. This pension provides income compensation up to a maximum of $70 \%$ of the last income for a maximum period of 5 years. At the end of that period the person's work ability has to be reassessed. The level of compensation is dependent on age, number of working years, and the level of work ability. Those whose ability to work is impaired by $80-100 \%$ are entitled to a full work disability pension while those whose ability to work is impaired by $15-80 \%$ are entitled to a partial work disability pension. In the Netherlands it is therefore possible to receive a work disability pension and to remain in employment, usually on a part time basis.

\section{WORK RELATED FACTORS}

Table 2 lists the results of the logistic regression analyses estimating the risk of withdrawal from the labour force associated with each work factor in separate models. All models were adjusted for confounding effects of age, sex, educational level, disease duration, and disease activity. Since functional ability was highly correlated to disease activity $(r>0.6)$, we chose to enter only the variable for disease activity into the models to prevent colinearity. Variables for the field of work show that patients who had withdrawn from the labour force worked 3.2 times more often in manual or industrial trades than those who still had a paid job. They were also 3.3 times less likely to have worked in part time jobs ( $<32$ hours a week) in their last job. Patients who still had a paid job reported 2.0 times more often that they had completed additional job training and 2.0 times more often that the disease had influenced their choice of last job position. Difficult access to the work place and reduced transport mobility were found to be 5.0 times more prevalent among patients who had withdrawn from the labour force, whereas job adjustments at the work place such as changes in working hours, adjusted job demands, or technical adjustments were reported 3.3 times less by those patients. In addition, relationships with people at work are important in terms of withdrawal from the labour force. Insufficient support from colleagues, colleagues not being well informed about the disease, and insufficient coaching were reported 3-5 times more often by patients who no longer worked.

COPING STYLES

The relations between various coping styles and withdrawal from the labour force are shown in table 3 . In order to cope with pain, patients who had withdrawn from the labour force were 3.6 times more likely to have reduced activity than patients who still had a paid job. They also reported diverting attention
1.6 times more often. In order to cope with limitations, pacing - for example, adapting one's level of activity - was reported 3.8 times more often by patients who had withdrawn from the labour force. With respect to dependence, no significant differences in coping styles were observed between patients with RA who had withdrawn and those still in the labour force.

WORK FACTORS AND COPING STYLES COMBINED Table 4 lists the results of the stepwise forward logistic regression for the combined effect of all work factors and coping styles adjusted for age, sex, education, disease duration, and disease activity. The variables are listed in order of their entry into the regression. Overall, the model shows that coping styles as well as work factors, particularly relationships with the management and colleagues and also organisational factors, contribute substantially to withdrawal from the labour force. When the proportion of patients who had withdrawn from the labour force was calculated in terms of each factor, it emerged that pacing in order to cope with limitations accounted for $67 \%$ of the withdrawals. The highest preventable risk fraction was adjusted job demands which accounted for $63 \%$ of the patients still in the labour force. Other important factors which showed high attributable fractions were insufficient coaching (48\%) and decreasing activity in order to cope with pain $(46 \%)$. Factors that showed high preventable fractions were "the disease had influenced the choice of the last job position" (48\%) and working part time $(42 \%)$.

Analysis of a subsample of patients who had withdrawn from the labour force during the 6 years before the study showed similar results. The factor with the highest preventable fraction was adjusted job demands (accounting for $50 \%$ of the patients still in the labour force). The factor "decreasing activities" in order to cope with pain showed the highest attributable fraction for withdrawal from the labour force (accounting for $46 \%$ of the withdrawals) (no further data shown).

\section{Discussion}

The findings of this study support the evidence of others that work related factors are important in the relation between RA and withdrawal from the labour force, ${ }^{29-11}$ and add a new element to previous studies of this relation by identifying behavioural coping as a potential risk factor which is as important as work related factors. Adjusting job demands seems to be the most important factor negatively associated with withdrawal from the labour force. Pacing in order to cope with limitations by, for example, adapting one's level of activity seems to be the major positively correlated factor. Only a few earlier studies have examined the independent effect of behavioural coping on illness outcome in RA, and only one study ${ }^{28}$ found that patients with RA used behavioural coping strategies more frequently than cognitive coping strategies when dealing with problems at work. Although the other studies did not specifically focus on work, our findings 
on coping in relation to work underline their findings that limiting the level of activity when facing the stressors of the disease is negatively associated with physical functioning. ${ }^{13} 1516$

Although our study shows that disease related variables differ significantly between patients who have withdrawn from the labour force and patients who still have a paid job, it does not provide answers to the question of whether disease related factors, work factors, or social factors are the most predictive for leaving the labour force. In contrast with other studies, we dealt with disease related factors as confounding variables in the relationship between RA and withdrawal from the labour force. ${ }^{911}$ It may be obvious that disease related factors are important and that medical treatment could have a positive influence on labour force participation. However, to maximise the reduction of early withdrawal from the labour force in patients with RA it is also important to examine modifiable factors at work and the psychosocial context. Our study therefore provides useful information for the implementation and evaluation of vocational rehabilitation programmes. ${ }^{9}$

Some of the work factors may seem easy to modify, but altering working conditions requires the cooperation of employers, colleagues, occupational health care, and financial incentives from employers, insurance companies, or the government. This cooperation is probably easier to achieve in times of economic growth than in times of recession. ${ }^{29}$ Little is known about the effect of modifying work related factors among patients with RA. One study by Allaire et al showed that younger patients with a relatively short duration of disease could benefit from interventions aimed at adjusting physically demanding jobs, commuting difficulties, and altering job type..$^{9}$ Modifying coping behaviour, on the other hand, requires the full cooperation of the employees themselves. Cognitivebehavioural coping interventions usually emphasise control of pain by understanding the interaction of emotions and cognition with the physical and behavioural aspects of pain. Controlled clinical trials of cognitive-behavioural coping interventions demonstrated improvements in active coping skills in patients with RA and found positive effects on clinical outcome and well being. However, the effects on work status have not yet been studied. ${ }^{170-32}$

It should be pointed out that our study has some methodological limitations. Data were collected by a self-administered questionnaire and we did not validate these data using objective measures. However, the questionnaire included several well validated instruments for assessing disease activity and outcome independent of work status. ${ }^{14}{ }^{20-25}$ It is therefore unlikely that our results were substantially and systematically affected in any direction by differential misclassification-that is, patients who had withdrawn would rate their disease activity and outcome systematically different from patients who still had a paid job.

Although data about work were collected retrospectively, we think that considerable recall bias is less likely because we found that work related factors and behavioural coping were also equally important in a subsample of patients who had recently withdrawn from the labour force.

With respect to coping, the cross sectional design of our study does not allow us to state that the explanatory variables have a causal relationship with withdrawal from the labour force. Our study does not rule out the competing explanation that withdrawal from the labour force invokes passive coping styles such as "decreasing activities" as a way of coping with pain and "pacing" as a way of coping with limitations. It is possible that behavioural coping and withdrawal from the labour force may be reciprocally interrelated, meaning that passive coping styles may induce withdrawal from the labour force which, in turn, will facilitate deleterious effects on behavioural coping. On the other hand, research on coping found that patients with RA may already develop a coping style early in the illness and use their favourite strategies when confronted with the stressors of illness. ${ }^{133}$ A more longitudinal approach is needed to assess whether the association between behavioural coping and withdrawal from the labour force is one of effect rather than cause and, furthermore, the extent to which coping skills are modifiable in relation to withdrawal from the labour force.

In summary, in addition to disease related factors, work related factors and behaviour coping styles should be considered in vocational rehabilitation for patients with RA as they are major determinants of withdrawal from the labour force.

The authors thank the following rheumatologists for their assistance with recruiting participants for the study: Dr A Linssen, Dr M Janssen, Dr A de Jong, Dr M Jeurissen, Dr P Jacobs, Dr P Seys, Dr H Haanen, Dr E ter Borg, Dr H Brus, Dr D Hofman, Dr W Hissink Muller, Dr H van Beusekom, Dr J van Emmerik, Dr J Koops-Korbee, Dr J Ewals, Dr H van der Leeden, Dr J Haverman, Dr P van Oyen, Dr R van Soesbergen, Dr G de Bruyn, Dr E Griep, Dr P Houtman, Prof Dr F Breedveld, Dr J Hazes, Dr H Bootsma, Dr B Hazenberg, Dr $M$ van Leeuwen, Prof Dr van Rijswijk, Dr
Santen-Hoeufft, and Dr A Boonen.

This work was supported by the Dutch Rheumatism Foundation and the Dutch Ministry of Health.

1 World Health Organization. ICIDH-2: International classification of functioning and disability. Geneva: World Health Organization, 1999

2 Yelin E, Henke C, Epstein W. The work dynamics of the person with rheumatoid arthritis. Arthritis Rheum 1987; 30:507-12.

3 Doeglas D, Suurmeijer T, Krol B, Sanderman R, van Leeuwen M, van Rijswijk M. Work disability in early rheumatoid arthritis. Ann Rheum Dis 1995;54:455-60.

4 Mau W, Bornmann M, Weber H, Weidemann HF, Hecker $\mathrm{H}$, Raspe HH. Prediction of permanent work disability in a follow-up study of early rheumatoid arthritis: results of a tree structured analysis using RECPAM. Br J Rheumatol 1996;35:652-9.

5 Sokka T, Kautiainen H, Mottonen T, Hannonen P. Work disability in rheumatoid arthritis 10 years after the diagnosis. J Rheumatol 1999;26:1681-5.

6 Wolfe F, Hawley DJ. The longterm outcomes of rheumatoid arthritis. Work disability: a prospective 18 year study of 823 patients. J Rheumatol 1998;25:2108-17.

7 Chorus AMJ, Miedema HS, Wevers CWJ, Linden SM vd. Labour force participation among rheumatoid arthritis patients. Ann Rheum Dis 2000;59:549-54.

8 Cochrane GM. Rheumatoid arthritis: vocational rehabilitation. Int Rehabil Med 1982;4:148-53.

9 Allaire SH, Anderson JJ, Meenan RF. Reducing work disability associated with rheumatoid arthritis: identification of additional risk factors and persons likely to benefit from intervention. Arthritis Care Res 1996;9:349-57.

10 Reisine S, McQuillan J, Fifield J. Predictors of work disability in rheumatoid arthritis patients. Arthritis Rheum 1995; 38:1630-7.

11 Yelin E, Meenan R, Nevitt M, Epstein W. Work disability in rheumatoid arthritis: effects of disease, social, and work factors. Ann Intern Med 1980;93:551-6. 
12 Reisine S, Grady K, Goodenow C, Fifield J. Work disability among wom with rheumatoid arthritis. Arthritis Rheum among women with

13 Newman SP, Revenson TA. Coping with rheumatoid arthritis. Bailliere's Clin Rheumatol 1993; 7:259-80.

14 Van Lankveld W, Naring G, van der Staak C, van't P, van de Putte L. Stress caused by rheumatoid arthritis: relation among subjective stressors of the disease, disease status, and well-being. J Behav Med 1993;16:309-21.

15 Van Lankveld W, Naring G, van't P, van de Putte L. Behavioral coping and physical functioning: the effect of adjusting the level of activity on observed dexterity. J Rheumatol 1999;26:1058-64.

16 Van Lankveld W, Naring G, van't Pad B, van de Putte L. The negative effect of decreasing the level of activity in coping with pain in rheumatoid arthritis: an increase in psychological distress and disease impact. J Behav Med 2000;23:377-91.

17 Bradley LA, Alberts KR. Psychological and behavioral approaches to pain management for patients with rheumatic approaches to pain management for patients with rhe

18 Miedema HS, Linden SMvd, Rasker JJ, Valkenburg HA. A national database of patients visiting rheumatologists in the Netherlands: The Standard Diagnosis Register of Rheumatic Diseases. A report and preliminary analysis. Br J Rheumatol 1998;37:555-61.

19 Mason JH, Anderson JJ, Meenan RF, Haralson KM, LewisStevens D, Kaine JL. The rapid assessment of disease activity (RADAR) questionnaire: validity and sensitivity to change of a patient self-report measure of joint count and clinical status. Arthritis Rheum 1992;35:156-62.

20 Stucki G, Liang MH, Stucki S, Brühlmann P, Michel BA. A self-administered rheumatoid arthritis disease activity index (RADAI) for epidemiologic research Arthritis Rheum 1995;38:795-8.

21 Bijlsma JWJ, Oude Heuvel CHB, Zaalberg A. Development of the Dutch questionnaire capacities of daily life (VDF) of patients with rheumatoid arthritis. J Rehabil Sci 1990;2: patients.
22 Andries F, Wevers CW, Wintzen AR, Busch HF, Howeler CJ, de Jager AE, et al. Vocational perspectives and neuromuscuar disorders. Int J Rehabil Res 1997;20:255-73.

23 Wevers CW, Brouwer OF, Padberg GW, Nijboer ID. Job perspectives in facioscapulohumeral muscular dystrophy. Disabil Rehabil 1993;15:24-8.

24 Nijboer ID, Wevers CJ. Vocational rehabilitation of young adults with a disability of one arm or hand. Int J Rehabil Res 1993;16:45-7.

25 Van Lankveld W, van't Pad B, van de Putte L, Naring G, van der Staak C. Disease- specific stressors in rheumatoid arthritis: coping and well-being. Br J Rheumatol 1994;33: 1067-73.

26 Armitage P, Berry G. Statistical methods in medical research. 2nd ed. Oxford: Blackwell Scientific Publications, 1987.

27 Rothman KJ, Greenland S. Modern epidemiology. 2nd ed. Philidelphia: Lippincott-Raven, 1998.

28 Blalock SJ, DeVellis BM, Holt K, Hahn PM. Coping with rheumatoid arthritis: is one problem the same as another? Health Educ Q 1993;20:119-32.

29 Shanahan EM, Smith MD. Rheumatoid arthritis, disability and the workplace. Bailliere's Best Pract Res Clin Rheumatol 1999;13:675-88.

30 Hawley DJ. Psycho-educational interventions in the treatment of arthritis. Bailliere's Clin Rheumatol 1995;9:803-23.

31 Scholten C, Brodowicz T, Graninger W, Gardavsky I, Pils K, Pesau B, et al. Persistent functional and social benefit 5 years after a multidisciplinary arthritis training program. Arch Phys Med Rehabil 1999;80:1282-7.

32 Keefe FJ, Van Horn Y. Cognitive-behavioral treatment of rheumatoid arthritis pain: maintaining treatment gains. Arthritis Care Res 1993;6:213-22.

33 Evers AW, Kraaimaat FW, Geenen R, Bijlsma JW. Psychosocial predictors of functional change in recently diagnosed rheumatoid arthritis patients. Behav Res Ther 1998;36: 179-93. 